\title{
The Relationship between Supervisor Safety, Safety Management Practices, and Safety Compliance Behaviour among Employees
}

\author{
Zuraida Hassan ${ }^{a^{*}}$, Rashidah Rahim ${ }^{b}$ \\ a School of Business Management, Universiti Utara Malaysia, 06010 UUM Sintok, Kedah, Malaysia \\ ${ }^{b}$ School of Science and Technology, Management and Science University Malaysia, 40100, MSU Shah Alam, Selangor, Malaysia \\ *Corresponding author: h.zuraida@uum.edu.my
}

Article history: Received 25 February 2019 Received in revised form: 05 April 2019 Accepted: 28 May 2019 Published online: 29 August 2019

\begin{abstract}
This cross-sectional research was conducted to establish the relationship between supervisor safety, safety management practices, and safety compliance behaviour among medical laboratory personnel in the private sector. There were 119 respondents from private medical laboratories in Selangor. The data were collected using a survey questionnaire adopted from past research that measured supervisor safety, safety management practices, and safety compliance behaviour. The data obtained from the study were analysed using SPSS. The findings show that supervisor safety has a positive correlation with safety compliance behaviour. Meanwhile, safety management practices were not significantly correlated to the dependent variable. The results of this study could give additional information to the private medical laboratory organisations in improving their safety practices and management for a safe and healthy work environment.
\end{abstract}

Keywords: Medical laboratory personnel, supervisor safety, safety management practices, safety compliance behaviour

\begin{abstract}
Abstrak
Kajian rentas ini dijalankan untuk menentukan hubungan antara faktor keselamatan penyelia, amalan pengurusan keselamatan, dan tingkah laku pematuhan keselamatan di kalangan kakitangan makmal perubatan di sektor swasta. Terdapat 119 responden dari makmal perubatan swasta di Selangor. Data yang dikumpulkan menggunakan soal selidik kaji selidik yang telah digunakan dalam penyelidikan terdahulu yang mengkaji faktor keselamatan penyelia, amalan pengurusan keselamatan dan tingkah laku pematuhan keselamatan. Data yang diperoleh daripada kajian ini kemudiannya dianalisis dengan menggunakan SPSS. Penemuan kajian menunjukkan bahawa faktor keselamatan penyelia mempunyai korelasi positif dengan tingkah laku pematuhan keselamatan. Sementara itu, amalan pengurusan keselamatan tidak berkait rapat dengan pemboleh ubah bersandar. Hasil kajian ini dapat memberikan maklumat tambahan kepada organisasi-organisasi makmal perubatan swasta dalam meningkatkan amalan dan pengurusan keselamatan mereka untuk persekitaran kerja yang selamat dan sihat.
\end{abstract}

Kata kunci: Kakitangan makmal perubahatan, keselamatan penyelia, amalan pengurusan keselamatan dan tingkah laku keselamatan

(C) 2019 Penerbit UTM Press. All rights reserved

\subsection{INTRODUCTION}

Laboratory medicine is a swiftly changing area where new technology and scientific advances are brought into medical practice. It was estimated that about 240 million pathology laboratory tests were carried out in Malaysia in 2006 (Looi, 2008), involving biochemistry, microbiology, haematology, blood transfusion, serology, parasitology, cytology, and histopathology fields. Thus, there is a necessity for qualified medical laboratory personnel to conduct these tests in various medical laboratories. As stated by the World Health Organization (WHO), healthcare laboratories must have a minimum standard to comply with contingent on the level and scope of laboratories. Safe working practices and the quality level of laboratories are associated with the reliability of laboratory results (Sewunet et al., 2014).

Laboratory personnel are frequently exposed to occupational hazards related to the clinical sample that they handle and analyse such as blood, body fluids, tissue of patients, and the methods they deploy in their work. Therefore, the workers may be highly exposed to contamination and risk of infection. A major concern ensuing occupational exposure of health care employees is probable transmission of blood-borne pathogens, particularly human immunodeficiency virus (HIV), hepatitis B virus (HBV) as well as hepatitis C virus (HCV) (Akhter et al., 2011).

Despite the importance of safety behaviour at the workplace, less is known about factors that are associated with safety compliance behaviour among the private medical laboratory personnel. Moreover, the Occupational Safety and Health Act 1994 in Malaysia does not give a specific protection to medical laboratory personnel (Narayan, 2013). Thus, safety compliance behaviour among medical laboratory personnel is compulsory to prevent accidents among them. This study aims to investigate the relationship between supervisor safety, safety management practices, and safety compliance behaviour among medical laboratory personnel in private medical laboratories in Malaysia. 


\subsection{LITERATURE REVIEW}

\section{Occupational Hazards in Medical Laboratories}

Infection due to blood-borne pathogens (BBP), particularly HIV infections, has considerable global awareness. Accidental occupational exposure of health care employees to blood and body fluids after skin injury or mucous membrane contact is the major risk of blood-borne pathogen transmission such as HIV, HBV, and HCV (Beltrami, Williams, Shapiro, \& Chamberland, 2000). Laboratory personnel are exposed to a substantial pool of specimens from patients suffering from infection such as HIV and HBV. They may be exposed to bloodborne pathogens during collection, processing, and analysing of patients' specimens (Annuar, Zahedi, Kadir, \& Mohktar, 2008). Shekar, Patel, Jain, Garg, and Mangukiya (2014) reported that a lack of awareness or hazardous laboratory practices during sample collection, processing, and discarding of specimens probably make the laboratory personnel more exposed to pathogens.

\section{Safety Compliance Behaviour}

Safety compliance behaviour may be described as activities employees should do to retain workplace safety (Neal \& Griffin, 2002) including keeping the standards of work procedures and using personal protective equipment (Neal \& Griffin, 2006). Jiang et al. (2010) stated that safety compliance is a behaviour that is sanctioned and expected of employees. According to Reason (1990), violations of safety standards and procedures will cause punishment, while compliance with safety may be rewarded. The major factors that contributed to positive safety compliance behaviour are management commitment, safety communication, safety leadership, effective safety training, safety rules and regulations, safety management system, safety motivation, safety and health officers, as well as personal protective equipment (Flin, Mearns, O'Connor \& Bryden, 2000). In this article, safety compliance behaviour refers to the compliance of universal precaution standards among the private medical laboratory personnel.

\section{Supervisor Safety}

A study by Zohar and Luria (2005) discovered that changing the supervisors' perception and knowledge of safety policies and practices, supplying monitoring tools, and rewarding safety performance led to a decrease in non-compliance incidences within the organisation. Supervisor safety and safety management practices play an important role in job satisfaction (Hayes et al., 1998). Vinodkumar and Bhasi (2010) concluded that a strong relationship between the supervisor and workers would improve safety climate as well as increase safety performance. Coaching supervisors to include safety in their daily communication with employees, visibility of management and supervisors, and leadership can give impact on safety behaviour (Zohar \& Luria, 2005). Mosher et al. (2011) found that safety perception of employees comes more from the management than the supervisors that they communicate every day.

\section{Safety Management Practices}

The management role and the involvement of employees as the key players in safety and health culture are vital to develop the positive beliefs, attitudes, and practices in the organisation. Mashi (2014) stated that management commitment to health and safety in the workplace can change the behaviour of their employees. Employers ought to have in place a system that includes written policy and protocols, monitoring, evaluation, counselling, treatments, and follow-ups of occupational exposure that may put employees at risk of blood-borne pathogen infection (Akhter et al., 2011).

\subsection{THEORETICAL FRAMEWORK}

The study intends to establish the relationship between supervisor safety, safety management practices, and safety compliance behaviour among medical laboratory personnel as shows in Figure 1. To answer the research question, the researchers developed the following hypotheses:

\section{H1: There is a significant relationship between supervisor safety and safety compliance behaviour of medical laboratory personnel;}

H2: There is a significant relationship between safety management practices and safety compliance behaviour of medical laboratory personnel.

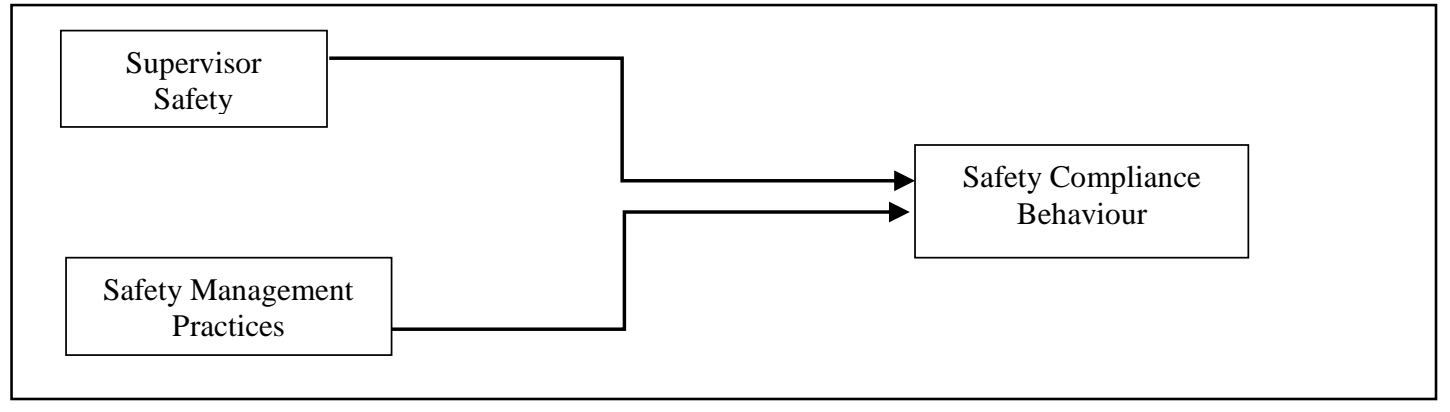

Figure 1 The relationship between supervisor safety, safety management practices, and safety compliance 


\subsection{METHODOLOGY}

This section discusses and explains the methodology of the study. It includes research design, population, sample size, data collection procedures, survey instrument(s), validity of instruments and the plan for data analysis.

\section{Research Design}

This cross-sectional study involved a one-shot data collection process. The study used a questionnaire as the instrument for data collection. The instrument was adapted from Hayes et al. (1998) and contained demographic questions, supervisor safety, safety management practices, and safety compliance behaviour items.

\section{Population and Sample Size}

The population of the study was 176 private medical laboratory workers located in Klang, Shah Alam, and Petaling Jaya, Selangor. The participants were drawn through a simple random sampling based on their job positions. Krejcie and Morgan (1970) specified that the sample size for a given population size is 123 respondents in this study. However, 140 survey questionnaires were distributed to the population. The respondents were laboratory managers, science officers, medical laboratory technicians, and laboratory assistants.

\section{Data Analysis Techniques}

The data collected were analysed using the Statistical Package for the Social Sciences (SPSS) software version 20.0 The data analysis process consisted of three stages, namely data filtering, demographic profiling and hypothesis testing. In hypothesis testing, the study employed correlation and regression analyses that examined the relationship between the dependent and independent variables.

\section{Pilot Test}

A pilot test was conducted before the actual data were collected, with the main purpose being to identify the reliability of the questionnaire adapted from past research. The result showed a significantly higher value of reliability of all items, above 0.70 . It's indicates a high level of internal consistency of the items (Sekaran \& Bougie, 2010).

\subsection{RESULTS AND DISCUSSION}

A total of 119 respondents were private medical laboratory workers, which located in Klang, Shah Alam, and Petaling Jaya, Selangor. More than $68.9 \%$ of the respondents are female. The results of demographic data statistic showed that $80.7 \%$ are Malay, followed by Chinese $(10.1 \%)$, Indians $(7.6 \%)$ and others like Iban and Bidayuh $(1.7 \%)$ respectively. The majority of the respondents were aged between 26 to 30 years old. As for the level of education, most of the respondents are a Diploma holder which contributes to 77 or $64.7 \%$ percent whereby 26 respondents or $21.8 \%$ are graduates with a Bachelor degree holder. Detailed demographic data are as shown in Table 1.

Table 1 Demographic Data of Respondents

\begin{tabular}{lcc}
\hline & Frequency & Percentage \\
\hline Gender & 37 & 31.1 \\
Male & 82 & 68.9 \\
Female & & \\
Age (Years) & 33 & 27.7 \\
$18-25$ & 46 & 38.7 \\
$26-30$ & 27 & 22.7 \\
$31-35$ & 10 & 8.4 \\
$36-40$ & 3 & 2.5 \\
$41-45$ & & \\
Education & 11 & 9.3 \\
SPM and equivalent & 77 & 64.7 \\
Diploma & 26 & 21.8 \\
Bachelor Degree & 5 & 4.2 \\
Others & & \\
\hline
\end{tabular}




\begin{tabular}{lcc}
\hline Race & 96 & 80.7 \\
Malay & 12 & 10.1 \\
Chinese & 9 & 7.6 \\
Indians & 2 & 1.7 \\
Others & & \\
Work Experiences (Years) & 16 & 13.4 \\
S1y & 49 & 41.2 \\
2-5y & 37 & 31.1 \\
6-9y & 14 & 11.8 \\
10-13y & 3 & 2.5 \\
<14y & & \\
Job Position & 6 & 5.0 \\
Lab Manager & 6.1 \\
Science Officer & 19 & 16.0 \\
Medical Laboratory Technologist (MLT) & 81 & 68.1 \\
Medical laboratory assistant & 9 & 7.6 \\
Others & 4 & 3.4 \\
\hline
\end{tabular}

As shown in Table 2, the descriptive values for the variables in this study. The result indicated the mean value 3.8916 for supervisory safety, 3.8899 for safety management practices and 3.787 mean value for safety compliance behaviour. In addition for standard deviation, the safety management practices indicated the highest score of 0.52049 while the supervisory safety scored only 0.46370 .

Table 2 Descriptive Analysis Result

\begin{tabular}{lccccc}
\hline & N & Minimum & Maximum & Mean & Std. Deviation \\
\hline Supervisor safety & 119 & 3.10 & 5.00 & 3.8916 & .46370 \\
& & & & & \\
$\begin{array}{l}\text { Safety } \\
\text { Practices }\end{array}$ & 119 & 2.60 & 5.00 & 3.8899 & .52049 \\
Compliance safety & 119 & 2.55 & 4.36 & 3.7387 & .34618 \\
\hline
\end{tabular}

Multiple regression analysis is used to determine the relationship between the variables. The findings of the analysis were shown by the in Table 3, Table 4 and Table 5. As shown in the Table 3 (Model summary), the correlation value (R) between the criterion variable and both predictor is 0.653 . The $\mathrm{R}^{2}$ value 0.427 shows that the change in the criterion variable (safety compliance behaviour) is due to change caused by the predictor variable. Adjusted $\mathrm{R}^{2}(0.401)$ is intended to estimate overestimates of the population $\mathrm{R}^{2}$ resulting from small samples, high collinearity or small subject or variable ratios. It is perceived utility varies greatly across research areas and time. In addition, the statistical findings summarized in Table 4 shows that the $\mathrm{F}$ value of 16.820 is a significant relationship between predictor variables and the dependent variable at $\mathrm{p}<0.05$ level of significance. As conclusion the independent variables factor which significantly $[\mathrm{F}$ $(5,113)=16.820, \mathrm{p}<0.05)$ contributes in the safety compliance behaviour which $\mathrm{r}=0.653$.

Table 3 Model Summary

Model Summary ${ }^{\mathrm{b}}$

\begin{tabular}{ccccc}
\hline Model & R & R Square & Adjusted R Square & Std. Error of the Estimate \\
\hline 1 & $.653^{\mathrm{a}}$ & .427 & .401 & .39472 \\
\hline
\end{tabular}

a. Predictors: (Constant), Safety Management Practices, Supervisor safety

b. Dependent Variable: Safety Compliance Behaviour 
Table 4 Anova Table

\begin{tabular}{ccccccc}
\multicolumn{7}{c}{ ANOVA $^{\mathrm{a}}$} \\
\hline Model & & Sum of Squares & Df & Mean Square & F & Sig. \\
\hline & Regression & 13.103 & 5 & 2.621 & 16.820 & $.000^{\mathrm{b}}$ \\
& Residual & 17.606 & 113 & .156 & & \\
Total & 30.709 & 118 & & & \\
\hline
\end{tabular}

a. Dependent Variable: Safety Compliance Behaviour

b. Predictors: (Constant), Safety Management Practices, Supervisor safety

The result shows in Table 5 indicated that there is a significantly relationship between the supervisory safety and the safety compliance behaviour with Beta value $=0.259(\mathrm{p}<0.05)$. This mean that hypothesis 1 was supported. In other hand, there is no significant relationship between the safety management practices and dependent variable with Beta value $=-0.118$ ( $\mathrm{p}>0.05$ ). Thus, hypothesis 2 was rejected.

Table 5 Standardised of Coefficient

Coefficients $^{\mathrm{a}}$

\begin{tabular}{|c|c|c|c|c|c|c|}
\hline & \multirow[b]{2}{*}{ Model } & \multicolumn{2}{|c|}{ Unstandardized Coefficients } & \multirow{2}{*}{$\begin{array}{c}\text { Standardized Coefficients } \\
\text { Beta } \\
\end{array}$} & \multirow[b]{2}{*}{$\mathbf{t}$} & \multirow[b]{2}{*}{ Sig. } \\
\hline & & B & Std. Error & & & \\
\hline \multirow[t]{3}{*}{1} & (Constant) & .813 & .567 & & 1.433 & .154 \\
\hline & Supervisor safety & .210 & .064 & .259 & 3.267 & .001 \\
\hline & Management safety & -.133 & .091 & -.118 & -1.466 & .146 \\
\hline
\end{tabular}

a. Dependent Variable: Compliance safety

Based on the above result, supervisors play an important role in creating and maintaining a positive occupational safety and health environment in the workplace as they work directly with the employees. They have a responsibility for complying with the law, enforcing the safety rules, conducting safety training as well as providing support and resources to the employees. Building a stronger relationship between the supervisors and employees can also promote a positive and safe climate in the workplace.

The result of the present study indicates that there is no significant relationship between safety management practices and safety compliance behaviour among the private medical laboratory personnel. This is most probably due to the employees working closely with their supervisors instead of directly with their top management. All the information regarding laboratory safety is provided directly by the supervisors. This result shows a gap in the workplace relationship between the employees and their top management regarding safety. It also indicates that the employees perceived their top management roles are not significantly related to their workplace safety.

\subsection{CONCLUSION}

Currently, there are about 300 private medical laboratories in Malaysia. In 2007, the Ministry of Health Malaysia (MoH) stated that about 44\% of 240 million pathology tests in Malaysia were conducted by private laboratories and their performances were monitored by the MoH under the Pathology Laboratory Act 2007 (Deputy Prime Minister, 2007 in Looi, 2008). All the laboratories must comply with safety requirements and run by qualified staff. Therefore, both the organisation and employees are responsible for ensuring a safe and healthy workplace. The medical laboratory personnel are exposed to various occupational hazards which could lead to injuries and diseases, and the hazards can vary depending on the nature of the organisation in which they are working. Hence, it is necessary to be aware and educate the employees about their occupational hazards and how to prevent these in order to protect their health and safety from the adverse effects of the hazards. Medical laboratories can be safe workplaces if both the organisation and employees comply with the safety procedures and standards. The employers and employees need to take advantage of the available engineering controls and work practices to prevent the exposure.

\section{References}

Akhter, J., Al Johani, S., Hammad, L. \& Al Zahrani, K., (2011) Laboratory Work Practices And Occupational Hazards Among Laboratory Health Care Workers: A Health And Safety Survey. Journal of Pharmaceutical and Biomedical Sciences, 9 (9), 1-4.

Anuar, I., Zahedi, F., Kadir, A., \& Mokhtar, A., (2008). Laboratory-Acquired Injuries in Medical Laboratory: A Survey of Three Referal Medical Laboratories from Year 2001 To 2005. Journal of Community Health, 14(1), 32-37.

Beltrami, E. M., Williams, I. T., Shapiro, C. N. \& Chamberland, M. E., (2000). Risk and Management of Blood-Borne Infections in Health Care Workers. Clinical Microbiology Reviews, 13(3), 385-407 
Deputy Prime Minister of Malaysia at the Opening of the 24th World Congress of Pathology and Laboratory Medicine, Kuala Lumpur, Malaysia. August 2007. In Looi, L. M., (2008). The Pathology Laboratory Act 2007 explained. Malaysian Journal Pathology, $30(1), 1$ - 10.

Hayes, B., Perander, J., Smecko, T., \& Trask, J. (1998). Measuring Perceptions of Workplace Safety: Development and Validation of Work Safety Scale. Journal of Safety Research, 29, 145-161.

Jiang, L., Yu, G., Li, Y., \& Li, F. (2010). Perceived Colleagues' Safety Knowledge/Behavior And Safety Performance: Safety Climate As A Moderator In A Multilevel Study. Accident Analysis \& Prevention, 42(5), 1468-1476.

Krejcie, R., \& Morgan, D. (1970). Determining Sample Size For Research Activities. Educational and Psychological Measurement, 30 , 607-610.

Looi, L. M., (2008). The Pathology Laboratory Act 2007 explained. Malaysian Journal Pathology, 30(1), 1-10.

Mahmood R, Mohd Isa M.F, Mustafa M, Abd Aziz F.S and Salleh A. (2010). Safety Behaviour: The Role Of Safety Commitment. College of Business, UUM. DOi: http://www.internationalconference.com.my/proceeding/icber2010 p

Mashi M.S. (2014) Moderating Effect Of Consideration Of Future Safety Consequence On The Relationship Between Safety Management Practices And Safety Performance Among Health Care Workers: A Conceptual Analysis. International Journal of Academic Research in Business and Social Sciences, 4(6), 402-411.

Mosher, G. A. (2011). Measurement And Analysis Of The Relationship Between Employee Perceptions And Safety And Quality Decision-Making In The Country Grain Elevator (Doctoral dissertation, Iowa State University).

Narayan, S. (2013). Knowledge, Attitude and Practice on Occupational Safety and Health among Medical Laboratory Personnel in Hospital Raja Permaisuri Bainun, Ipoh - Impact of Intervention. Bachelor Science (Hons) Biomedical Science. Department of Biomedical Science, Faculty of Science, Universiti Tunku Abdul Rahman. http://eprints.utar.edu.my/905/1/BM-2013-1000038-2.pdf.

Neal, A. \& Griffin, M. A. (2002) Safety Climate and Safety Behaviour. Australian Journal of Management, 27(1), 67-75.

Neal, A., \& Griffin, M. A. (2006). A Study Of The Lagged Relationships Among Safety Climate, Safety Motivation, Safety Behavior, And Accidents At The Individual And Group Levels. Journal of Applied Psychology, 91(4), 946-953.

Pathology Laboratory Act 2007 (Act 674). Kuala Lumpur: Percetakan Nasional Malaysia Berhad. August 2007.

Sekaran, U, \& Bougie;R (2010) Research Methods For Business A Skill Building Approaches (5th Edition) UK John Wiley and Sons.

Seo, D.C., Torabi, M.R., Blair, E.H., \& Ellis, N.T. (2004). A Cross-Validation Of Safety Climate Scale Using Confirmatory Factor Analytic Approach. Journal of Safety Research, 35, 427-445.

Sewunet, T., Kebede, W., Wondafrash, B., Workalemau, B., \& Abebe, G. (2014) Survey of Safety Practices Among Hospital Laboratories in Oromia Regional State, Ethiopian Journal of Health Sciences, 24 (4), 307-310.

Shekhar, H., Patel, M., Jain, C., Garg, N., \& Mangukiya, K. (2014) Laboratory Biosafety Manual, 2nd Ed. Geneva:

Vinodkumar, M. N., \& Bhasi, M. (2010). Safety Management And Safety Behaviour: Assessing The Mediating Role Of Safety Knowledge And Motivation. Accident Analysis and Prevention, 42, 2082-2093.

Wu, C., Song, X., Wang, T., \& Fang, D. (2015). Core Dimensions Of The Construction Safety Climate For A Standardized Safety-Climate Measurement, Journal of Construction Engineering and Management, 141 (8), 1-12.

Zikmund, W. G. Babin, B.J, Carr, J.C., \& Griffin M (2013). Business Research Method 9th Edition. Mason OH South Western: Ohio.

Zohar, D., \& Luria, G. (2005). Climate as a Social-Cognitive Construction Of Supervisory Safety Practices: Scripts As Proxy Of Behaviour Patterns. Journal of Applied Psychology, 89(2), 322-333. 